\title{
Correction \\ Correction: Haddad et al. Reviving Alexander Calder's Man-Eater with Pennants: A Technical Examination of the Original Paint Palette. Heritage 2021, 4, 1920-1937
}

\author{
Abed Haddad *, Megan Randall, Lynda Zycherman (D) and Ana Martins
}

check for

updates

Citation: Haddad, A.; Randall, M.;

Zycherman, L.; Martins, A.

Correction: Haddad et al. Reviving

Alexander Calder's Man-Eater with

Pennants: A Technical Examination of the Original Paint Palette. Heritage 2021, 4, 1920-1937. Heritage 2022, 5, 460. https://doi.org/10.3390/

heritage 5010026

Received: 8 February 2022

Accepted: 11 February 2022

Published: 1 March 2022

Publisher's Note: MDPI stays neutral with regard to jurisdictional claims in published maps and institutional affiliations.

Copyright: () 2022 by the authors Licensee MDPI, Basel, Switzerland. This article is an open access article distributed under the terms and conditions of the Creative Commons Attribution (CC BY) license (https:// creativecommons.org/licenses/by/ $4.0 /)$.
The David Booth Conservation Department, The Museum of Modern Art, 11W 53rd Street, New York, NY 10019, USA; megan_randall@moma.org (M.R.); lynda_zycherman@moma.org (L.Z.); 2021amartins@gmail.com (A.M.)

* Correspondence: abed_haddad@moma.org or abedhaddad123@gmail.com

The authors wish to make the following corrections to this paper [1].

In the published manuscript, the first line in the abstract reads "Mat-Eater with Pennants" and should read "Man-Eater with Pennants".

In the published manuscript, page number 1925, the C.I. number for chrome yellow (P.Y. 34) reads "C.I. 77,600". Convention in writing C.I. numbers does not require the use of a comma, which is reflected in the remaining instances of using C.I. numbers throughout the published manuscript. Thus, the line should read "C.I. 77600".

In the published manuscript, reference [15] reads "Zycherman, L. Calder Foundation, New York, NY, USA. Personal communication, 2021". Lynda Zycherman is a sculpture conservator at The Museum of Modern Art, and thus the reference should read " $\mathrm{Zy}$ cherman, L. Correspondence with the Calder Foundation, New York, NY, USA. Personal communication, 2021".

The authors apologize for any inconvenience caused and state that the scientific conclusions are unaffected. The original article has been updated.

\section{Reference}

1. Haddad, A.; Randall, M.; Zycherman, L.; Martins, A. Reviving Alexander Calder's Man-Eater with Pennants: A Technical Examination of the Original Paint Palette. Heritage 2021, 4, 1920-1937. [CrossRef] 